\title{
Mi historia COVID. Una vivencia bastante cercana
}

\author{
My COVID story. A very close experience
}

\author{
Gretel Lozano Guerrero*
}

Citar como: Lozano GG. Mi historia COVID. Una vivencia bastante cercana. Acta Med. 2021; 19 (1): 157-158. https://dx.doi.org/10.35366/98595

Señor editor:

A través del siguiente relato me gustaría compartir mi experiencia al haber tenido COVID y los sentimientos que lo acompañaron, hacerles saber a quienes lo lean cómo se vive y a los que ya lo padecieron, a identificarse con las emociones que se experimentan a cada momento. No se sientan solos.

\section{EL CONTAGIO}

Decir dónde, cuándo y cómo me contagié sigue siendo un enigma, algo que nunca sabré. ¿Fue en el súper, en el hospital, por un colega o alguien de enfermería? Lo que sí sé es que mis síntomas comenzaron un viernes, el 8 de mayo para ser exactos, considerando que el tiempo de incubación tiene una media de cinco días, y el confinamiento inició el 28 de marzo. iTenemos un sospechoso, mi querido Watson! Sí, el medio hospitalario.

\section{LA NEGACIÓN}

\section{El inicio de la enfermedad}

Para entonces la información era escasa, de la evolución y el cuadro se sabía muy poco, "sin fiebre no es COVID", se decía, ahora sabemos que no es así, pero las mañanas frías en la Ciudad de México me hicieron creer que mi tos "sólo era enfriamiento", lo dejé pasar. Hasta el momento no se sabía de nadie enfermo en el

\footnotetext{
* Médico Residente de Pediatría, Hospital Ángeles Pedregal.

Ciudad de México, México.
}

Correspondencia:

Dra. Gretel Lozano Guerrero

Correo electrónico: gretel.lozano@gmail.com

www.medigraphic.com/actamedica hospital, entonces no crecieron mis sospechas, en fin, la negación.

La tos ya no era sólo en las mañanas y se iba intensificando, fue el miércoles 13 de mayo, una mañana bastante fría que me dejó sentir un dolor en el pecho de una tos bastante intensa, pero que aun así me dejó llegar al hospital. Ya habían pasado cinco días desde el inicio de los síntomas, los cuales me negaba siquiera a considerar. Inicié mi jornada entre partos, historias clínicas y dar informes, el aire me iba faltando cada vez más hasta que el dolor del pecho me hizo pensar en un broncoespasmo. iClaro, mis alergias! La molestia fue avanzando y pedí que me revisaran. "Se escucha limpio", me dijeron, "si te sientes muy mal baja a urgencias para que te nebulicen". Por fortuna no lo hice, me libré del remordimiento de saber que pudiese haber propiciado un contagio mayor. Me tomé una placa de tórax, se veía normal, pero llegó un punto que incluso sentada la disnea era evidente, el mínimo esfuerzo me ocasionaba toser a tal grado que casi dejaba el pulmón a medio camino.

No estaba nada convencida de que fuera COVID, pero nebulización tras nebulización pasaron dos días sin mejoría evidente, el mínimo esfuerzo era un martirio, no poder siquiera vestirme complicó mi día a día hasta que entendí que no podría hacer la siguiente guardia. Tomé el celular y le marqué a mi jefe, "doctor, me siento muy mal, estoy con broncoespasmo y no creo poder hacer la guardia del sábado", "habla con enseñanza y coméntales, yo creo que tienes COVID, tómate ahora dos ivermectinas y me avisas qué te dicen, pero para mí que es COVID", me respondió. Colgué y llamé de inmediato al jefe de enseñanza: "ven mañana a urgencias para que te valoren y me avisas. Estoy al pendiente".

\section{EL MIEDO A LA INCERTIDUMBRE}

\section{El diagnóstico}

Sábado por la mañana, a una semana del inicio, acudí a valoración, se gestionó que me tomaran una PCR. Es tan 
fácil como médico decir "hazte la prueba... tómate esto... haz aquello", pero ser paciente y sentir el isopo tocar hasta tus pensamientos es una sensación que nadie olvida. Recuerdo entrar con desdén al área de toma de muestras, seguía negada a pesar de la disnea, se suponía que sólo se enfermaban personas mayores con comorbilidades, yo no cumplía con los criterios, pero al virus parecía no importarle, "las enfermedades no estudian los libros de medicina" $y$ sin fiebre, anosmia o disgeusia iclaro que no era COVID! Las verdades del ayer son las mentiras del ahora, claro está.

Regresé a mi casa, sentí alivio en cierta forma y aún no sé por qué, pero fue hasta el domingo por la tarde que recibí un mensaje preguntando cómo estaba y si ya sabía mi resultado. Lo revisé en WhatsApp y no entendía, el jefe de enseñanza me escribía que tenía que estar en casa 15 días y después acudir a revaloración; lo vi de nuevo, lo releí y lo volví a leer. ¿Era positivo? El miedo fue mi único compañero en ese momento: ¿cómo evolucionaría?, ¿me ocurriría lo mismo que a los pacientes cuyas notas leía en todas las entregas de guardia?, ¿cuál sería el mejor hospital para internarme en caso de necesitarlo? Mil y una preguntas, con cada una se acrecentaba el miedo. Le avisé a mi hermana que era la única que lo sabría, no quise alterar a mi madre para no preocuparla, estando tan lejos no le veía el caso. La pauta por seguir: aislamiento, tratamiento sintomático, pronación y ver la evolución sin saber qué pasaría.

El diagnóstico se supo en el hospital, muestras de apoyo me acompañaron en mi aislamiento, Uber Eats se encargó de mi alimentación y así en posición de prono se marcaron las almohadas en mis mejillas. Medía la saturación transcutánea todos los días y enviaba el reporte diario de la evolución por mensaje a la jefatura de enseñanza; mi hermana me llamaba más de dos veces al día, preocupada por si tuviese que tomar un vuelo a la Ciudad de México en las próximas horas, icon quién dejaría a sus hijos o cómo le diría a mi mamá lo que estaba pasando? Ahora entiendo que dejé caer una carga muy grande en ella.

\section{LA MEJORÍA}

Al pasar de los días el estar en cama pesaba más y más, me atreví a abrir la puerta, a caminar un poco más, los baños ya no eran tan pausados, sutilmente notaba la mejoría. Monitoreaba mis síntomas con un artículo que, aunque era en pacientes ingresados a una unidad hospitalaria, me hacía sentir que me alejaba cada vez más de una cama de hospital. La tos llegó para quedarse, mes y medio duró y aunque no desaturaba, siempre me encontraba en límites bajos, pero con el paso de los días comencé poco a poco a estar en pie y no acostada.

Durante el curso de la enfermedad lo que más llevaré para siempre conmigo son las emociones que la acompañaron: un miedo terrible rozando en el pánico, el hacer conciencia de padecer una enfermedad de la que se entendía poco y se sabía menos, con tantos tratamientos de entre los tantos artículos que salían diariamente probados en tres o cinco pacientes, de lo único que estaba segura es que cuando algo tiene tantos esquemas, ninguno sirve. Las desconocidas y posibles secuelas aunadas a la incertidumbre de la gran posibilidad de haber contagiado a quién sabe cuántas más víctimas por mi negación y todo potencializado por la soledad, consecuencia del aislamiento que era la principal indicación de mi receta médica.

Y así llegó el final de los 15 días, a una semana sin síntomas más allá de la tos, acudí entonces a consulta; en la sala de espera vi pasar a personal del hospital uno tras otro al igual que yo en búsqueda de una respuesta y sólo podía pensar "estamos cayendo como moscas". Me tocó mi turno: "lo que tuvo fue una neumonitis por COVID, doctora, por eso sólo la tos y le va a durar en lo que se desinflame el pulmón, pero como tiene más de tres días sin síntomas puede ya regresar a trabajar". Y así fue como me dieron el alta, pero no perdí el miedo, miedo a las secuelas de las cuales ya se empezaba a hablar.

\section{SENTIRSE COMO BICHO RARO}

\section{De regreso a la cotidianidad}

Al regresar, todos, absolutamente todos, sabían que me había contagiado, hacían bromas y me daban la bienvenida, y aun así me sentía señalada. Para entonces el número de contagios no se acercaba al actual; hoy en día todos conocen, saben o han escuchado de alguien que se ha contagiado, enfermado o muerto por COVID. Comenzaron a distribuir mascarillas N95 a todos en el hospital, me dio gusto ver incluso al personal de limpieza portando su cubrebocas. Me sentí segura, tranquila, como hacía ya varios días que no me sentía; y puesto que los niños no dejan de nacer, incluso en las peores crisis o pandemias, el trabajo me fue absorbiendo y el cansancio de estar en cama pasó a ser el alivio de una jornada. 